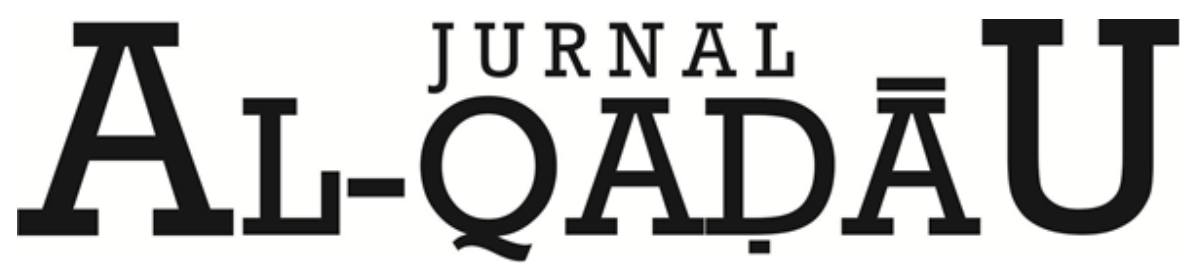 \\ PERADILAN dan HUKUM KELUARGA ISLAM
}

\section{Profesional Nazhir Wakaf dalam Pemberdayaan Ekonomi}

\section{Wakaf Nazhir Professionals Towards Economic Empowerment}

Musyfikah Ilyas

Dosen UIN Alauddin Makassar

Email : musyfikah.ilyas@uin-alauddin.ac.id

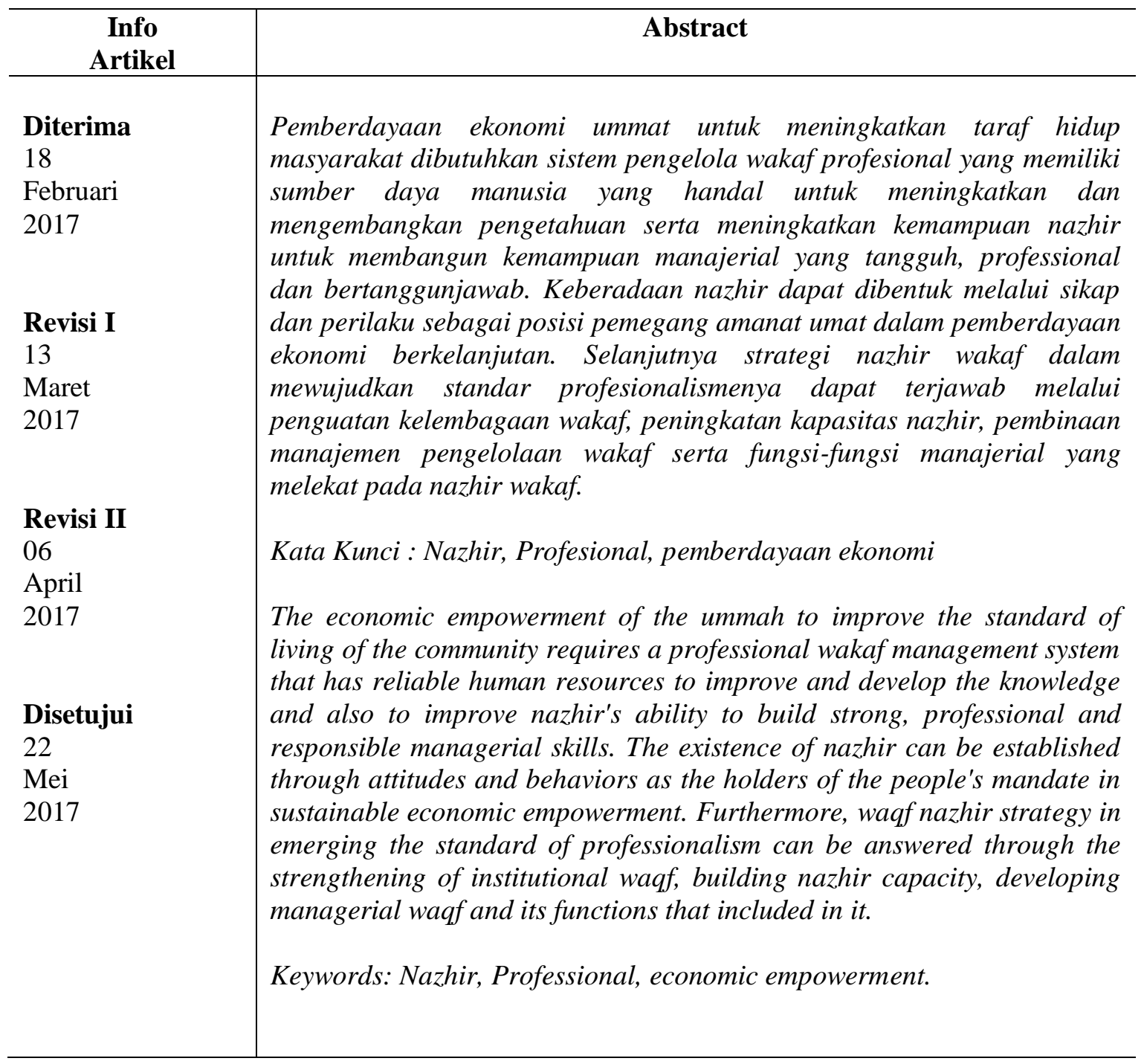


Musyfikah Ilyas

\section{PENDAHULUAN}

\section{A. Latar Belakang}

Kedudukan nazhir merupakan suatu hal yang sangat penting dan sentral karena pihak yang menerima harta benda wakaf dari wakif untuk dikelola dan dikembangkan sesuai dengan peruntukannya dinamakan dengan nazhir. Nazhir inilah yang bertanggung jawab untuk memelihara, menjaga dan mengembangkan wakaf agar wakaf dapat berfungsi sebagaimana yang diharapkan yang dilaksanakan sesuai dengan tujuan syariat.

Pengelolaan dan pengembangan harta benda wakaf secara produktif dilakukan antara lain dengan cara pengumpulan, investasi, penanaman modal, produksi, kemitraan, perdagangan, agrobisnis, pertambangan, perindustrian, pengembangan teknologi, pembangunan gedung, apartemen, rumah susun, pasar swalayan, pertokoan, perkantoran, sarana pendidikan ataupun sarana kesehtan dan usaha-usaha yang tidak bertentangan dengan syariah. Jadi nazhir adalah pengelola harta benda wakaf yang tugasnya mengelola dan mengembangkan harta benda wakaf sesuai dengan peruntukannya. ${ }^{1}$

Berdasarkan hasil survey yang dilakukan CSRC menunjukkan jumlah nazhir yang bekerja secara penuh sangat minim (16\%). Umumnya mereka bekerja Sambilan (84\%). Mereka melakukan pekerjaan tetap, seperti nazhir PNS/swasta, petani pedagang dan sebagainya yang harus diutamakan di samping tugas sebagai nazhir. Kenyataan ini menggambarkan, bahwa profesi nazhir bukanlah profesi yang diharapkan dalam masyarakat. Hal ini terjadi karena rendahnya pendapatan yang diterima nazhir dari pekerjaan sebagai pengelola wakaf. Hasil survey yang menunjukkan hanya sebagian kecil nazhir yang mengaku menerima gaji sebagai nazhir (8\%). Dari yang menerima gaji, sebagian besar menyatakan bahwa gaji yang mereka terima tidak memadai (82\%). Disamping itu nazhir dipilih bukan atas dasar professional, tetapi karena ketokohan, kerabat dekat waqif, ataupun karena kepercayaan wakif. ${ }^{2}$

Nazhir yang tidak professional mengakibatkan banyak harta yang wakaf yang

\footnotetext{
${ }^{1}$ Racmadi usman, Hukum Perwakafan Di Indonesia (Cet. II; Jakarta: Sinar Grafika, 2013), h. $134-135$

${ }^{2}$ Rozalinda, Manajemen Wakaf produktif (Cet. I; Jakarta: Rajawali Press, 2015), h. 52
} 
tidak berfungsi secara maksimal dan memberi manfaat yang sedikit sebagaimana yang diharapkan, bahkan banyak harta yang beralih fungsi atau terjual kepada pihak-pihak yang tidak bertanggung jawab, karena nazhir tidak megelola harta benda wakaf secara professional. Untuk itu diperlukan profesionalisme nazhir dalam mengelola wakaf, agar wakaf memberikan kesejahteraan social dan ekonomi masyarakat maka perlu memberdayakan wkaf, sehingga dapat meningkatkan kesejahteraan ummat Islam pada khususnya dan masayarakat pada umumnya.

\section{B. Rumusan Masalah}

Berdasarkan latar belakang diatas, maka permasalahan dapat dirumuskan sebagai berikut :

1. Bagaimana reposisi nazhir dalam pengembangan kapasitas kelembagaan nazhir?

2. Bagaimana bentuk professionalime nazhir dalam pemberdayaan ekonomi ?

\section{PEMBAHASAN}

\section{A. Reposisi Nazhir dalam Pengembangan Kapasitas Kelembagaan}

Dalam literatur fikih pengelola wakaf disebut nazhir yang berarti penjaga, manajer, admibistrator, kepala atau direktur. Selain itu disebut mutawwali, yang berarti pengurus, yang diberi kuasa dan berkomitmen, eksekutif, manajer dan direktur. Nazhir adalah orang atau pihak yang berhak untuk bertindak terhadap harta wakaf, baik untuk memelihara, mengerjakan berbagai hal yang memungkinkan harta itu tumbuh dengan baik maupun mendistribusikan hasilnya kepada orang yang berhak menerimanya. ${ }^{3}$ Nazhir adalah pihak yang menerima harta benda wakaf dari wakif untuk dikelola dan dikembangkan sebagaimana peruntukannya. Nazhir meliputi :

a. Nazhir Perorangan

Nazhir perorangan disyaratkan (a) warga negara Indonesia (b) beragama Islam (c) dewasa (d) amanah (e) mampu jasmani dan rohani dan (f) tidak terhalang melakukan perbuatan hukum

${ }^{3}$ Sukron Kamil, Ekonomi Islam, Kelembagaan dan Konteks Keindonesiaan Dari Politik Makro Ekonomi Hingga Realisasi Mikro (Cet. I; Jakarta: Rajawali Pers, 2016), h.162 
Musyfikah Ilyas

b. Nazhir Organisasi

Organisasi Nazhir merpakan organisasi harus bergerak dibdang social, pendidikan, kemasyarakatan dan/atau keagamaan Islam yang memenuhi persyaratan sebagai berikut (a) pengurus organisasi harus memenuhi persyaratan persyaratan nazhir perorangan, (b) salah seorang pengurus organissi harus berdomisili di kabuaten/kota letak benda wakaf benda; (c) memiliki: 1. salinan akta notaris tentang pendirian dan anggaran 2. daftar susunan pengurus 3. anggaran rumah tangga 4. program kerja dalam pengembangan wakaf 5. daftar kekayaan yang berasal dari harta wakaf yang terpisah dari kekayaan lain atau yang merupakan kekayaan organisasi; dan 6. surat pernyataan bersedia untuk diaudit.

c. Nazhir Badan Hukum

Nazhir badan hukum merupakan badan hukum Indonesia yang bergerak di bidang social, pendidikan, kemasyarakatan, dan/atau keagamaan Islam; b. Pengurus badan hukum harus memenuhi persyaratan nazhir perseorangan; c. salah seorang pengurus badan hukum harus berdomisili di kabupaten/kota benda wakaf berada; d. memiliki: 1. Salinan akta notaris tentang pendirian dan anggaran dasar badan hukum yang teah disahkan oleh instansi berwenang; 2. Daftar susunan pengurus; 3. Anggaran rumah tangga; 4. Program kerja dalam pengembangan wakaf; 5. Daftar terpisah kekayaan yang berasal dari harta benda wakaf atau yang merupakan kekayaan badan hokum dan 6 . Surat pernyataan bersedia untuk diaudit.

Nazhir mempunyai tugas :

a. Melakukan pengadministrasian harta benda wakaf

b. Mengelola dan mengembangkan harta benda wakaf sesuai dengan tujuan, fungsi peruntukannya

c. Mengawasi dan melindungi harta benda wakaf

d. Melaporkan pelaksanaan tugas kepada Badan Amil Wakaf Indonesia. ${ }^{4}$

Masa Bakti Nazhir

Masa bakti nazhir adalah 5 tahun dan dapat diangkat kembali. Pengangkatan kembali dilakukan oleh Badan Wakaf Indonesia, apabila melaksanakan tugasnya dengan baik dalam periode sebelumnya sesuai dengan ketentuan syariah dan

\footnotetext{
${ }^{4}$ Pasal 11 Undang-undang Nomor 41 tahun 2004 tentang Perwakafan
} 
perundang-undangan. Para ulama berpendapat lain jika seorang nazhir kemudian tidak melaksanakan tugasnya dnegan berkhianat membelanjakan harta benda wakaf yangtidak sesuai peruntukannya atau nazhir mengundurkan diri, maka pemerintah dan wakif boleh memberhentikan dan menyerahkan kepada orang yang bersedia untuk menjalankan tugas sebagai untuk mengelola harta benda wakaf.

Pemberhentian nazhir dan diganti oleh nazhir yang lain dalam mengembangkan pengelolaan dan pengembangan harta wakaf dalam undang-undang dijelaskan:

a. Meninggal dunia bagi bagi nazhir perorangan

b. Bubar atau dibubarkan sesuai dengan ketentuan peraturan perundang-undangan yang berlaku untuk nazhir organisasi dan nazhir badan hukum

c. Atas permintaan sendiri

d. Tidak melaksanakan tugasnya sebagai nazhir dan/atau melanggar ketentuan larangan dalam pengelolaan dan pengembangan harta benda wakaf sesuai dengan ketentuan peraturan perundang-undangan yang berlaku.

e. Dijatuhi hukuman pidna oleh pengadilan yang telah mempunyai kekuatan hukum tetap.

Seorang nazhir professional dalam mengelola harta wakaf harus mengacu pada prinsip-prinsip manajemen modern. Kata professional berasal dari kata profesi berarti pekerjaan di mana seorang hidup dari pekerjaan tersebut, dilakukan dengan mengandalkan keahllian, keterampilan yang tinggi serta melibatkan komitmen yang kuat.

Ciri atau karateristik professional yaitu: pertama, mempunyai keahlian dan keterampilan khusus untuk dapat menjalankan pekerjaan dengan baik. Keahlian dan keterampilan ini biasanya dimiliki dari pendidikan, pelatihan dan pengalaman yang diperoleh dalam jangka waktu tertentu. Pengetahuan, keahlian dan keterampilan ini memungkinkan orang yang professional mengenali dengan baik dan tepat dari persoalan tersebut. Dengan pengetahuan dan keterampilan itu memungkinkan seorang professional menjalankan tugasnya dengan tingkat keberhasilan dengan mutu yang baik. Kedua, adanya komitmen moral tinggi. Untuk profesi pelayanan social, komitmen moral dituangkan dalam bentuk kode etik profesi. Etika ini merupakan peraturan yang harus dijalankan dalam melaksanakan pekerjaan. Kode etik profesi ini 
Musyfikah Ilyas

ditujukan untuk melindungi masyarakat dari kerugian dan kelalaian, baik sengaja, maupun tidak dan ditujukan untuk melindungi profesi tersebut dari perilaku-perilaku tidak baik. Ketiga, orang yang professional, biasanya hidup dari profesi yang digelutinya. Ia di bayar denga gaji yan layak sebagai konsekuensi dari pengerahan seluruh tenaga, pikiran, keahlian, dan keterampilan. Keempat, pengabdian kepada masyarakat, adanya komitmen moral yang tertuang dalam kode etik profesi di mana orang-orang yang mengemban suatu profesi lebih mengutamakan kepentingan masyarakat daripada kepentingan dirinya. Kelima, legalisasi, keizinan. Untuk profesi yang menyangkut kepentingan orang banyak yang terkait dengan nilai-nilai kemanusiaan, maka profesi tersebut haruslah profesi yang sah dan diizinkan. ${ }^{5}$

Nazhir professional adalah orang yang melakukan pekerjaan purna waktu hidup dari pekerjan itu dengan mengandalkan kahlian dan keterampilan yang tinggi serta punya komitmen yang tinggi atas pekerjaannya. Seorang nazhir yang wakaf dianggap professional jika nazhir melakukan pekerjaan karena ia ahli di bidang itu, mengerahkan waktu, pikiran, dan tenaganya untuk pekerjaan tersebut. Oleh karena itu, seorang yang professional mempunyai komitmen yang kuat atas pekerjaannya. Komitmen pribadi inilah yang melahirkan tanggung jawab yang besar dan tinggi atas pekerjaannya. Manajemen Sumber Daya Manusia

Pengelolaan dan pengembangan nazhir menjadi bagian yang asangat penting dari tugas manajemen organisasi pengelola wakaf. Seberapa baik SDM dikelola akan menetukan kesuksesan organisasi ini di masa mendatang. Sebaliknya, jika SDM tidak dielola dengan baik, efektivitas pengelolaan wakaf tidak akan tercapai. Nazhir merupkan salah satu unsur yang paling vital bagi organisasi pengella wakaf. Hal ini terjadi Karen nazhir sangat memengaruhi efesiensi dan efektifitas organisasi. Begitu pentingnya manajemen SDM ini, bila diabaikan, organisasi tidak akan berhasil mencapai tujuan dan sasarannya. Untuk itu dalam rangka meningkatkan kemampuan nazhir, diperlukan system manajeman SDM yang handal yang bertujuan untuk :

\footnotetext{
${ }^{5}$ Departemen Agama RI Direktorat Pengembangan Zakat dan Wakaf Direktorat Jenderal Bimbingan Masyarakat Islam dan Penyelenggaraan Haji, Nazhir Profesioanl dan Amanah (Jakarta: Direktorat Pengembangan Zakat dan Wakaf, 2005), h. 75-78. Rozalinda, Manajemen Wakaf Produktif (Cet.I; Jakarta: Rajawali Pers, 2015), h. 53.
} 
1. Meningkatkan dan mengembangkan pengetahuan, kemampuan dan keterampilan nazhir dalam rangka membangun kemampuan manajerial yang tangguh, professional dan bertanggung jawab.

2. Membentuk sikap dan perilaku nazhir wakaf yang sesuai dengan ahlak alkarimah.

3. Menciptakan pola pikir atau persepsi yangsama dalam memahami dan menerapkan pola pengelolaan wakaf baik dari segi undang-undangwakaf maupun teknis manajeial sehingga dengan mudah melakukan pengontrolan baik di pusat maupun di daerah.

4. Menagajak para nazhir wakaf utu emahami tata cara pengelolaan yag lebih tiggi berorientasi pada keentingan pelaksanaan syaraita iSlam secar lebih lus shingga wakaf bisa menjadi salah satu elemen penting dalam menunjang penerapan system ekonomi syariat secara terpadu. ${ }^{6}$

Untuk mencapai pengelola wakaf yang profesional diperlukan pembinaan agar mereka dapat menjalankan tugas-tugas dengan profesional pula. Pembinaan dilakukan dengan menggunakan standar manajemen yang kekinian, pendidikan formal dan non formal, pelatihan, atau bimbinagan sehingga mampu menghasilkan pengelola dan pengembang harta benda wakaf.

Manajemen profesional yang baik dalam lembaga kenazhiran dapat dilihat dari tiga aspek, yaitu :

1. Transparansi

Transparansi adalah apsek yang penting yang tak terpisahkan dalam rangkaian kepemimpinan yang diajarkan oleh nilai-nilai Islam. Transparansi merupakan hal terpenting dalam pengelolaan dana umat seperti harta benda wakaf, maka harus lebih terbuka dalam pengelolaan. Pengelolaan dan pemberdayaan harta wakaf serta pemanfaatan hasilnya memerlukan transparansi, karena sejalan dengan ajaran Islam khususnya dalam pertanggungjawabannya. Untuk mengetahui sejauh mana praktek pertanggungjawaban tersebut dilapangan, maka bentuk pertanggunjawaban nazhir wakaf dapat kita lihat beberapa jenis pengawasan

${ }^{6}$ Rozalinda, Manajemen Wakaf produktif, h. 55-56 
Musyfikah Ilyas

diantaranya pengawasan Manajerial. ${ }^{7}$ Manajemen pengelolaan menempati posisi paling urgen dalam dunia perwakafan. Karena yang paling menentukan benda wakaf itu bermanfaat atau tidak tergantung pada pola pengelolaan, bagus atau buruk. Kalau pengelolaan benda-benda wakaf selama ini hanya dikelola dengan menggunakan managemen kepercayaan dan sentralisme kepemimpinan yang mengesampingkan aspek pengawasan, maka dalam pengelolaan wakaf harus menonjolkan sistem manajemen yang profesional. Sehingga dari manajemen seperti ini dapat diketahui ada atau tidaknya sebuah penyimpangan. Karena dalam teori manajemen modern, usaha preventif untuk menghindari potensi penyelewengan seseorang dilakukan dengan menerapkan sistem control. Pengawasan manajerial dalam pengelolaan wakaf produktif dilakukan dengan cara menuntut tingginya kualitas kepemimpinan dalam lembaga keNadziran. Lembagalembaga Nazhir yang ada tidak boleh didominasi oleh struktur kepengurusan yang otoriter dan tertutup melainkan harus mampu menjalankan roda kepemimpinan dengan berpegang teguh dengan tiga aspek berikut ini : Pertama, kepemimpinan yang transparan. ${ }^{8}$ Dengan transparansi ini roda kepemimpinan bisa dikontrol dengan baik. Oleh karena itu, transparansi harus menjadi ciri utama yang harus dilakukan oleh sorang pemimpin. Ketika aspek transparansi sudah ditinggalkan, maka kepemimpinan tidak akan berjalan dengan baik, bahkan membuka peluang terjadinya penyelewengan yang tak terkendali. Transparansi ini harus dijadikan tradisi supaya tindakan ketidakjujuran, korupsi, manipulasi dan yang lainnya dapat terdeteksi. Transparansi adalah aspek penting yang tak terpisahkan dalam rangkaian kepemimpinan yang diajarkan oleh nilai-nilai Islam. Konsepsi prinsipprinsip dasar akuntansi adalah, adanya prinsip-prinsip dasar keterbukaan penuh (transparansi) adalah karena begitu banyak peristiwa yang sebenarnya berkitan dengan posisi keuangan lembaga tapi tidak bisa dipaparkan melalui laporan keuangan, maka prinsip keterbukaan mengharuskan lembaga untuk membeberkan berbagai fakta yang relevan pada laporannya sehingga pembaca bisa memperoleh

\footnotetext{
${ }^{7}$ Departemen Agama, Model Pengembangan Wakaf Produktif (Jakarta: Direktorat Jenderal Bimbingan Masyarakat Islam Direktorat Pemberdayaan wakaf, 2008), h. 117.
}

${ }^{8}$ Departemen Agama, Model Pengembangan Wakaf Produktif, h. 118 
informasi yang sebenarnya tentang lembaga dari laporan keuangan yang diterbitkannya. Pengungkapan informasi itu bisa dilakukan dalam bentuk laporan atau sebagai catatan kaki dari laporan keuangan. Juga perlu diketahui juga bahwa setiap data harus dicatat secara obyektif dan bisa dibuktikan sehingga akuntan lain yang menghadapi situasi serupa bisa bisa sampai ke kesimpulan yang sama. Tujuannya adalah menjaga kredibilitas laporan keuangan. Gerakan untuk mempelopori transparansi dalam semua aspek kelembagaan Nazhir, baik dalam lingkup internal maupun eksternal wajib dimanifestasikan. Adanya transparansi kelembagaan Nazhir ini merupakan tindakan yang bersifat sistemik untuk menutup tindakan korupsi manipulasi dan sebagainya. Transparansi adalah aspek penting yang tak terpisahkan dalam rangkaian menegakkan amanah perwakafan yang diajarkan oleh nilai-nilai Islam. Sehingga lembaga wakaf dalam Islam bisa dijadikan tolak ukur keterbukaan dalam mengemban tanggung jawab moral para Nazhir menuju tatanan hidup bermasyarakat yang berkeadaban dan berkeadilan semesta. Kedua, kepemimpinan yang mengedepankan pertanggungjawaban umum (public accountability). ${ }^{9}$ Kewajiban lembaga nazhir adalah memelopori terjadinya iklim akuntabilitas public dalam pengelolaan harta wakaf. Dengan adanya public accountability pelaksanaan kepemimpinan bisa berpijak pada sifat amanah (dapat dipercaya) dan shiddiq (jujur). Karena kepercayaan dan kejujuran memang harus dipertanggungjawabkan, baik di dunia maupun di akhirat kelak. Sehingga dengan demikian, wakaf dapat dijadikan wahana yang sangat menjanjikan untuk kepentingan kesejahteraan masyarakat yang kredibel (sangat dipercaya) dengan tetap menjunjung tinggi nilai profesionalisme kerja yang beretos kerja baik. Eksistensi wakaf produktif memiliki kontribusi yang cukup penting dalam pemberdayaan masyarakat. Memberdayakan masyarakat berarti melakukan perubahan ke arah masyarakat yang lebih baik yang identic dengan pembangunan yang berarti perubahan, kemajuan (progres), yaitu peningkatan bidang-bidang kehidupan yang memang diarahkan kepada tujuan yang hendak dicapai. Kemudian pemberdayaan pada level petugas perwakafan adalah dengan melakukan pengembangan sumber daya manusia, yang tidak sekedar membentuk manusia

\footnotetext{
${ }^{9}$ Departemen Agama, Model Pengembangan Wakaf Produktif, h. 119
} 
professional dan terampil yang sesuai dengan kebutuhan system untuk dapat memberikan kontribusinya di dalam proses pembangunan, tetapi menekan pentingnya kemampuan manusa, kemampuan untuk mengaktualisasikan segala potensinya sebagai manusia. Ketiga, kepemimpinan yang aspiratif ${ }^{10}$ yaitu mau mendengar dan mengakomodir dinamika lembaga kenazhiran. Seorang nazhir yang dipercaya mengelola harta milik umum harus mendorong terjadinya system sosial yang melibatkan partisipasi banyak kalangan. Hal ini dilakukan untuk menghindari pola pengambilan keputusan secara sepihak oleh kalangan elit kepemimpinan. Sehingga mengurangi, bahkan menutup potensi-potensi yang berkembang, yang bisa mungkin jauh lebih baik atau sempurna. Kaedah prinsip dalam gerakan yang aspiratif merupakan cermin dari sifat adil dalam diri atau lingkungannya. Pola kepemimpinan seperti disebutkan diatas tersebut tentu membantu terciptanya situasi yang kondusif dalam pengawasan wakaf produktif. Selain pola kepemimpinan seperti di atas pengelolaan operasional dalam pelaksanaan wakaf produktif juga signifikan untuk dijadikan pengawasan manajerial. Yang dimaksud dengan standar operasional pengelolaan wakaf adalah batasan atau garis kebijakan dalam mengelola wakaf agar menghasilkan sesuatu yang lebih bermanfaat bagi kepentingan masyarakat banyak. Keempat, dalam kerangka menjaga akuntabilitas dan pertanggungjawaban, ${ }^{11}$ yang bermakna menjadi keseimbangan hubungan antara pihak-pihak yang terlibat dalam ikatan bisnis atau keperluan lainnya, Islam menegaskan urgensi pencatatan setiap transaksi atau hubungan niaga yang dilakukan. Hal ini dimaksudkan untuk menghindari kemungkinan persoalan yang akan timbul. Makna filosofis dan kemanusiaan proporsional pencatatan (akuntansi) demi menjaga keharmonisan hubugan pihak-pihak yang terikat dalam bekerjasama. Hal ini merupakan refleksi kedamaian yang memang menjadi garis besar haluan Islam.

2. Pertanggungjawaban umum

Pertanggungjawaban umum merupakan wujud dari pelaksanaan sifat amanah (kepercayaan) dan siddiq (kejujuran). Karena kepercayaan dan kejujuran memang

\footnotetext{
${ }^{10}$ Departemen Agama, Model Pengembangan Wakaf Produktif, h. 120

${ }^{11}$ Departemen Agama, Model Pengembangan Wakaf Produktif, h. 125.
} 
harus bertanggungjawaban oleh pelakunya baik di dunia maupun di akhirat. Pertanggungjawaban terhadap pengelolaan wakaf dan pemberdayaan wakaf menjadi penting terutama dalam memanfaatkan hasil yang diperoleh dari harta benda wakaf produktif dan memilki potensi.

Tanpa adanya rasa tanggung jawab dari nazhir wakaf maka harta yang dipercayakan kepadanya akan terbengkalai dan tidak terurus. Oleh karena itu, setiap orang yang dipercaya menduduki lembaga kenazhiran harus dipastikan bahwa orang tersebut memiliki tanggung jawab moral, sehingga dikemudian hari tidak akan terjadi kesewenangan, penyimpangan dan atau ketidakmampuan manajemen dalam pengelolaan wakaf.

Aspek tanggung jawab oleh nazhir menjadi kunci yang paling pokok dari seluruh rangkaian dunia perwakafan. Kalau rasa tanggung jawab ini tidak dimiliki oleh nazhir, maka wakaf hanya sebagai institusi keagamaan yang tidak berfungsi apapun, bahkan akan menjadi beban masyarakat. ${ }^{12}$

Selanjutnya ada dua aspek penting dalam kaitannya dengan pengawasan manajerial wakaf produktif, yakni aspek akunting dan auditing. Pada awalnya, akuntansi lebih diwarnai dan terbatas pada aspek pertanggungjawaban belaka. Namun dalam perkembangannnya, akuntansi mengalami transformasi sebagai salah satu sumber informasi dalam pengambilan keputusan bisnis. Ini membawa konsekuensi, misalnya pada bentuk dan kandungan laporannya bila dalam tahapan awal ada penekanan yang berlebih pada aspek neraca, misalnya kemudian beralih pada aspek laba rugi. Berdasarkan tujuan dasar dan pola operasi sebuah entitas, akuntansi dapat dipilah menjadi dua, yakni akuntansi untuk organisasi yang bermotifkan mencari laba (profit oriented organization) dan akuntansi untuk organisasi nirlaba (non profit oriented organization), dan wakaf yang dikelola secara lebih produktif dalam bentuk usaha komersial termasuk kategori yang pertama. Selanjutnya adalah aspek auditing. Dalam bahasa Indonesia biasanya auditing diartikan sebagai pemeriksaan. Yang dimaksudkan adalah bahwa pihak tertentu melaporkan secara terbuka tugas atau amanah yang diberikan kepadanya,

\footnotetext{
${ }^{12}$ Departemen Agama RI Direktorat Pengembangan Zakat dan Wakaf Direktorat Jenderal Bimbingan Masyarakat Islam dan Penyelenggaraan Haji, Fiqh Wakaf (Jakarta: Direktorat Pengembangan Zakat dan Wakaf, 2005), h. 105.
} 
dan pihak yang memberikan amanah mendengarkan. Jadi ini merupakan manifestasi pertanggungjawaban pihak tertentu yang diberi tanggung jawab kepada pihak yang diberi amanah. Dalam konteks lembaga wakaf, akuntansi dan auditing memiliki fungsi pengawasan serta berperan sebagi alat yang dapat dipergunakan untuk mencapai tujuan tertentu. Tujuan tersebut adalah merujuk pada tujuan lembaga wakaf itu sendiri. Dan secara umum, semua lembaga wakaf dibentuk atau didirikan adalah mengelola sejumlah kekayaan wakaf agar manfaat maksimalnya dapat dicapai untuk kesejahteraan umat umumnya, dan menolong mereka yang kurang mampu pada khususnya. Seiring dengan wacana Islamisasi, maka seyogyanya praktek akuntansi dan auditing yang akan dipakai sepenuhnya harus memperhatikan apa yang dipandang lebih mendekati atau sesuai dengan prinsip Syari'ah itu sendiri. Dan kemampuan manajemen operasional lembaga kenadziran harus didukung oleh aspek pendukung manajemen modern dalam system ekonomi berdasarkan Syariat Islam. ${ }^{13}$

Melihat fenomena penyimpangan dalam proses akuntansi, Islam bersikap sangat jelas, tidak akan pernah mentolerirnya. Melalui surah al-Baqarah ayat 282, Allah swt menegaskan Hai orang-orang yang beriman, apabila kamu bermu'amalah tidak secara tunai untuk waktu yang ditentukan, hendaklah kamu menuliskannya. dan hendaklah seorang penulis di antara kamu menuliskannya dengan benar. dan janganlah penulis enggan menuliskannya sebagaimana Allah mengajarkannya, meka hendaklah ia menulis, dan hendaklah orang yang berhutang itu mengimlakkan (apa yang akan ditulis itu), dan hendaklah ia bertakwa kepada Allah Tuhannya, dan janganlah ia mengurangi sedikitpun daripada hutangnya.

Dari ayat tersebut kita dapat melihat tekanan Islam kepada akuntansi dalam menjalankan peranannya. Pertama, sikap kejujuran (adil) yang mmutlak dipegang bagi seorang pencatat (akuntan). Perintah ini mengandung konsekuensi. Jika melakukan ketidakjujuran, dampaknya bukan kekacauan dalam arus pencatat itu sendiri, hal ini terbukti secara empiris ketidakjujuran itu berdampak serius bagi hajat hidup banyak kalangan. Dengan mencermati makna subtansial dari sikap Islam terhadap persoalan etika atau moral akuntan, kita diingatkan bahwa akuntan

\footnotetext{
${ }^{13}$ Departemen Agama, Model Pengembangan Wakaf Produktif, h. 123-125.
} 
yang menjunjung tinggi etika akan memberikan suasana kooperatif bagi pihakpihak yang berkepentingan, di samping kemanfaatan luas yang dirasakan publik. ${ }^{14}$

3. Standar operasional

Standar operasional pengelolaan wakaf adalah batasan atau garis kebijakan dalam mengelola wakaf agar menghasilkan sesuatu yang lebih bermanfaat bagi kepentingan masyarakat banyak. Menurut istilah manajemen dikatakan dikatakan bahwa yang disebut dengan pengelolaan operasional adalah proses-proses pengambilan keputusan berkenaan dengan fungsi operasional.

Dalam istilah manajeman dikatakan bahwa yang disebut dengan pengelolaan operasional adalah proses-proses pengambilan keputusan berkenaan dengan fungsi operasi. Pengelolaan operasional ini terasa sangat penting dan menentukan berhasil tidaknya manajemen pengelolaan secara umum. Adapun standar operasional itu meliputi seluruh rangkaian program kerja yang dapat menghasilkan sebuah produk (barang atau jasa). Standar keputusan operasional merupakan tema pokok dalam operasi kelembagaan Nazhir. Keputusan yang dimaksud di sini berkaitan dengan lima fungsi utama manajemen operasional, yaitu: proses, kapasitas, sediaan (inventory), tenaga kerja, dan mutu. Keputusan mengenai proses termasuk proses fisik, berkenaan dengan fasilitas yang akan dipakai untuk memperoduksi barang atau jasa. Juga menyangkut tipe peralatan dan teknlogi, arus proses, penyususnan fasilitas dan aspek-aspek lain yang menyangkut peralatan secara fisik atau fasilitas saja. Keputusan mengenai ini harus diperhitungkan secara matang karena pada umumnya akan terus dipakai dalam jangka waktu yang panjang dan tidak mudah diubah-ubah, terlebih jika menyangkut investasi yang cukup besar. Keputusan mengenai kapasitas diperlukan untuk menghasilkan jumlah produk yang tepat, ditempat yang tepat dan dalam waktu yang tepat pula. Kapasitas jangka panjang ditentukan dari ukuran fasilitas fisik yang dipakai. Adapun untuk jangka pendek, kapasitas dapat diperbanyak melalui subkontrak, tambahan gilir-kerja (shift) atau menyewa tempat. Perencanaan kapasitas tidak hanya menyangkut besarnya fasilitas, tapi juga menyangkut jumlah orang yang dibutuhkan dalam pengoperasiannya. Keputusan

\footnotetext{
${ }^{14}$ Departemen Agama, Model Pengembangan Wakaf Produktif, h. 126
} 
berkaitan dengan sediaan ini mencakup apa yang akan dipesan, berapa banyak, dan kapan dipesan. Keputusan berkaitan dengan tenaga kerja adalah pengelolaan SDM yang mana merupakan hal yang sangat penting dalam operasional lembaga kenazhiran, mengingat tidak ada sesuatu yang dapat diselesaikan tanpa SDM yang mencukupi. Yang terakhir, mutu sebagai salah satu fungsi terpenting dari bagian operasi adalah bertanggung jawab atau mutu barang atau jasa yang dihasilkan. ${ }^{15}$

4. Efesien, merupakan salah satu dari inti pengelolaan organisasi atau kelebangaan adalah efesiensi, tanpa efesiensi lembaga kenazhiran tidak akan optimal dalam pengelolaan dan pemberdayaan wakaf. Efesiensi terkait dengan penggunaan biaya administrasi dan kegiatan yang terkait dengan aspek pembiayaan dalam pengelolaan harta wakaf, sehingga dengan pola yang efesien, maka akan tercipta lembaga yang professional.

Pengelolaan operasional sangat menentukan keberhasilan manajemen pengelolaan secara umum. standar operasional meliputi seluruh rangkaian program kerja yang dapat menghasilkan produk (barang atau jasa). ${ }^{16}$ setiap tindakan dan aktivitas nazhir disesuaikan dan dilihat signifikansinya dengan kepentingan harta wakaf atau penerima. ${ }^{17}$ standar operasional kelembangan nazhir yang ingin mengelola secara produktif harta benda wakaf, memerlukan enam fungsi utama manajemen operasional, yaitu:

1. Proses, yang berkenaan dengan fasilitas yang akan dipakai untuk memproduksi barang atau jasa;

2. Kapasitas, yang berkaitan dengan hasil dan jumlah produk yang tepat.

3. Tenaga kerja, yang berkaitan dengan kesiapan sumber daya manusia

4. Mutu, yang berkaitan dengan bentuk dan peningkatan kualitas

5. Kehumasan, yang berkenaan dengan penguatan, keyakinan dan pengetahuan masyarakat; dan

\footnotetext{
${ }^{15}$ Departemen Agama, Model Pengembangan Wakaf Produktif, h. 121-123
}

${ }^{16}$ Departemen Agama RI Direktorat Pengembangan Zakat dan Wakaf Direktorat Jenderal Bimbingan Masyarakat Islam dan Penyelenggaraan Haji, Paradigma Baru Wakaf di Indonesia (Cet. II; Jakarta: Direktorat Pengembangan Zakat dan Wakaf, 2005), h. 108-109

${ }^{17}$ Ahrul Sani Faturrahman dkk, Hukum Wakaf: Kajian Kontemporer Pertama dan terlengkap tentang Fungsi dan Pengelolaan Wakaf serta Penyelesaian atas Sengketa Wakaf (Cet. I; Jakarta: Dompet Dhuafa Republika dan IImanN, 2004), h. 490 
6. System keuangan, yag berkaitan dengan akuntansi dan audit.

Operasionalisasi pengelolaan dan pemberdayaan wakaf yang didasarkan pada standar yang disebutkan di atas, dimaksudkan untuk mendapatkan hasil yang maksimal. Hasil yang diperoleh tersebut dapat dimanfaatkan secara luas bagi kepentinnngan masyarakat secara umum. wakaf produktif pada umumnya berupa tanah pertanian atau perkebunan, gedung-gedung komersiall yag dikelola sedemikian rupa, sehingga mendatangkan keuntungan. ${ }^{18}$ keuntungan yang dihasilkan sebagiannya dipergunakan untuk membiayai berbagai program kegiatan yang dilakukan oleh nazhir dalam meningkatkan produktifits harta wakaf.

Pengelolaan dan potensi wakaf produktif secara operasional oleh nazhir sematamata untuk kepentingan kesejahteraan umat manusia, khususnya muslim di Indonesia yang sampai saat ini masih dalam keterpurukan ekonomi yang sangat menyedihkan. Pemberdayaan potensi wakaf produktif membutuhkan keberdaan nazhir yang professional, bahkan menempati oposisi sentral.

\section{B. Bentuk Professionalime Nazhir dalam Pemberdayaan Ekonomi}

Aturan-aturan syariah untuk investasi wakaf Adalah wajib bagi para pemegang amanat harta wakaf; apakah nazhir, lembaga, atau lembaga atau institusi apapun yang megelola harta wakaf untuk memelihara keutuhan harta wakaf dan menjamin kesinambungan manfaatnya. Para pengelola harta wakaf bertanggung jawab kepada wakif, para mauquf alaih dan masyarakat secara umum, disamping tentunya dan terutamabertanggung jawab kepad Allah atas harta kekayaan wakaf yang memang dalam syariah merupakan harta yang haram dialhgunakan, baik dengan cara pengelolaan yang salah (mis-management), ataupun dengan ketidak-cermatan memilih bidang investasi yang sesuai dan mengakibatkan terjadi penyelewengan.

Penting pengelola wakaf memperhatikan aturan-aturan yang telah ditetapkan syariah sebelum pengambilan keputusan menginvestasikan harta keakayaan wakaf apakah keputusan itu terkait dengan pemilihan bidang ivestasi harta kekayaan wakaf,

\footnotetext{
${ }^{18}$ Uswatun Hasanah, "Perkembangan Wakaf di Dunia Islam”. Dalam Suhrawardi K. Lubis, dkk, Wakaf dan Pemberdayaan Umat (Cet. I; Jakarta: Sinar Grafika, 2010), h. 21.
} 
Musyfikah Ilyas

apakah keputusan itu terkait dengan pemilihan bidang usaha investasi secara umum, tukar guling harta wakaf, investasi keuntungan usaha wakaf, maupun pemilihan antara usaha pemiliharan dan tukar guling dan sebagainya. Sebelum menguraikan lebih lanjut mengenai aturan-aturan syariah tersebut perlu memperhatiakn sifat dan karakteristik harta kekayaan wakaf yang berbeda dengan unit-unit ekonomi dan usaha waralaba sebagai berikut:

1. Diversifikasi harta wakaf, para ulama fiqh dan ahli hukum Islam membagi harta kekayaan wakaf ke dalam tiga kategori, yaitu:

a. Wakaf tidak bergerak, seperti tanah, gedung, taman, kebun, mata-air, pabrik, gedung sekolah, rumah sakit kuburan dan semacamnya; yakni harta yang ditahan aslinya dan manfaat atau keuntungannya diberikan kepada kebajikan ataupun orang-orang yang berhak. Jenis harta benda wakaf ini selau memerlukan pemeliharaan, pengelolaan, dan kemungkinan besar tukar guling agar tetap memberikan manfaat dan kegunaan;

b. Wakaf bergerak, seperti kendaraan, kendaraan, hewan, perkakas, pakaian dan semacamnya; yakni harta yang ditahan aslinya dan maanfaat atau keuntungannya diberikan kepada kebajikan ataupun orang-orang yang berhak. Jenis harta wakaf ini juga selalu memerlukan pemeliharaan,pengelolaan dan kemungkinan besar tukar guling agar tetap memberikan manfaat dan kegunaan.

c. Wakaf uang dan semacamnya, seperti surat-surat berharga kepda lembagalembaga keuangan syariah yang dapat diinvestasikan untuk dimanfaatkan keuntungannya menjadi bantuan social. Menurut mazhab malikiayah wakaf uang diiperbolehkan dan tlah ada fatwa mengenai wakaf uang, wakaf saham dan wakaf sukuk.

2. Diantara karakteristik harta wakaf juga adalah menahan pokoknya dan memanfaatkan keuntungannya. Hal ini tentunya memerlukan upaya pelestarian sekaligus pengelolaan untuk memperolh keuntungan lebih besar. Dalam mengambil keputusan investasi harta wakaf, karakteristik harta wakaf demikian harus menjadi pertimbangan utama agar harta pokoknya beserta potensi ekonominya tetap terpelihara. 
3. Harta wakaf tidak boleh berpindah kepemilikan, tidak oleh nazhir tidak pula oleh siapapun pengelola wakaf kecuali melalui tukar guling yang dimaksudkan untuk pengembangan dan peningkatan usaha dan hasil-hasilya. Hal ini memerlukan pengkajian berbagai laternatif dan kemungkina-kemungkinan yang lebih menguntungkan.

4. Memperkecil resiko kerugian investasi. Adalah wajib menghindarkan harta kekayaan wakaf dari usaha investasi yang beresiko tinggi, misalnya dalm Bursa Efek, industry dengan resiko tinggi, atau menyerahkan pengelolaan investasi harta wakaf kepada yang tidak ahli. Untuk itu usaha investasi yang baik bagiharta wakaf adalah pada bidang usaha yag memberi keuntungan stabil.

5. Kemungkinan harta wakaf mengalami kerusakan atau potensi ekonominya semakin berkurang sehingga perlu pemeliharaan yang berkesinambungan dan mempelajari kemungkinan-kemungkinan yagng dapat meningkatkan daya produksinya. ${ }^{19}$

Prinsip-prinsip Syariah dalam Investasi Harta Wakaf

Berikut beberapa asas syariah yang harus dipenuhi untuk melakukan investasi wakaf:

1. Asas legalitas, yakni kegiatan investasi dilakukan pada proyek-proyek yang halal atau yang tida diharamkan. Maka tidak boleh menginvestasikan harta wakaf dengan cara membuka deposito pada bank-bank riba, membeli saham perusahaan yang bergerak di bidang usaha yang diharamkan, atau berinvestasi di negara-negara yang memerangi Islam Islam dan umat Islam ataupun kerjasama yang memerangi uat Islam.

2. Asas baik dan bersih, yakni investasi pada proyek-proyek yang bergerak di bidang usaha yang baik, bersih dan tidak kotor.

3. Asas prioritas Islam, yakni menyusun proyek-proyek investasi yang akan dibiayai dengan wakaf sesuai dengan skala prioritas sesuai dengan kebutuhan umat Islam.

\footnotetext{
${ }^{19}$ Kementerian Agama RI, Strategi Pengembangan Wakaf Di Tengah Kondisi Ekonomi Tak Menentu (Jakarta: Direktorat Jenderal Bimbungan Masyarakat Islam Direktorat Pemberdayaan Wakaf, 2011), h.135-136
} 
Musyfikah Ilyas

4. Asas pembangunan regional, yakni mengembangkan investasi wakaf di wilayah yang lebih dekat kepada lembaga wakaf memberi modal kecuali umat Islam di wilayah tersebut tak memerlukan lagi.

5. Asas pendapatan lebih besar bagi mauquf'alaihi terutama kaum fakir, yakni, megarahkan investasi wakaf kepada proyek-proyek yang menghasilkan keuntungan lebih besar bagi fakir miskin seperti membuka lapangan kerja bagi mereka sebagai prasyarat pembangunan social yang menjadi tujuan utama wakaf.

6. Asas memperoleh keuntungan ekonomi yang lebih memuaskan, yakni melakukan perhitungan agar memperoleh hasil maksimal secara ekonomi sehingga disamping dapat membayar keawjiban kepada para mauquf juga disisihkan untuk dana pemeliharaan dan pengelolaan karena agama mewajibkan adanya keseimbangan antara pembangunan social dan pembangunan ekonomi.

7. Asas pemeliharaan keutuhan harta wakaf dan pengembangannya, yakni sedapat mgkin menghindarkan harta wakaf dari resiko kerugian yang mengakibatkan rusak atau hilangnya sehingga diperlukan adanya semacam jaminan untuk mengeliminir resiko tersebut. Disamping perlunya menganut keseimbangan antara perhitungan hasil dan keamanan. Termasuk dalam hal ini tdak diperbolehkan adanya penumpukan harta karena tdak sesuai dengan hokum agama.

8. Asas keseimbangan, yakni keseimbangan antara jatuh tempo, bentuk investasi, kegiatan operasional, dan bidang usaha agar menjamin terhindarkan tesiko tinggi dan pada saat yang sama menghasilkan keuntungan yang lebih besar. Maka tidak boleh misalnya berfokus pada satu kota saja dan mengabaikan yang lain, atau memilih investasi jangka pendek saja dan meninggalkan investasi jangka menengah dan jangka panjang, ataupun focus pada bentuk permodalan tertentu dan mengabaikan bentuk-bentuk laninnya. Keseimbangan dan diversifikasi pengembangan wakaf dapat menghindarkan resiko tinggi.

9. Asas kejelasan kontrak, yakni semua pihak yang terikat dalam proyek investasi harus mengetahui seberapa keuntungan yang akan diperoleh masing-masing dan seberapa kerugian yang harus ditanggung masing-masing. Semuanya harus 
tertuang dalam kontrak yangdilegalisir sehingga tidak mengundang keraguan dan perselisihan. Hal itu telah ditekankan Allah dalam firman-Nya dalam Q.S. al-Baqarah (2) : 282:

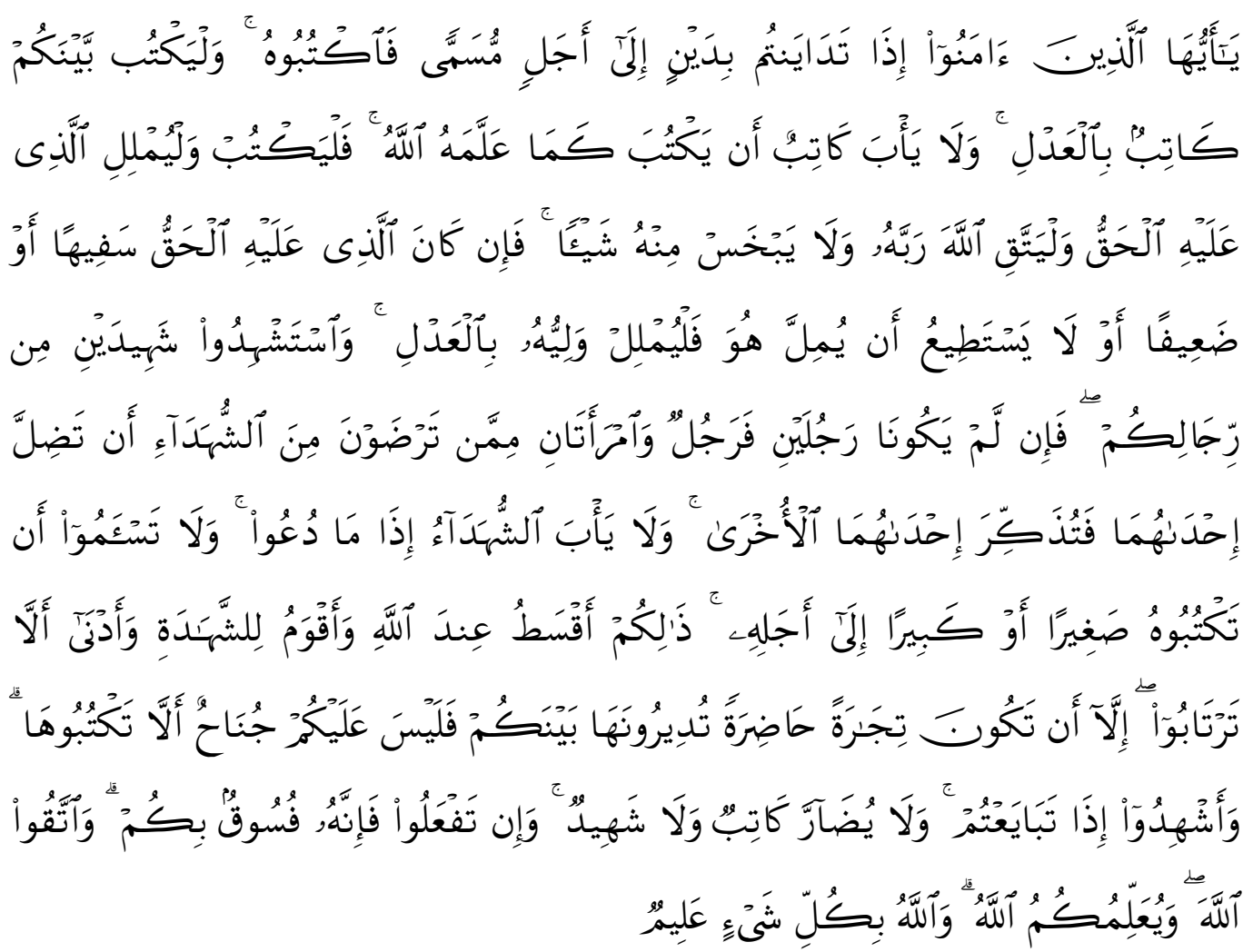

Artinya: Hai orang-orang yang beriman, apabila kamu bermu'amalah tidak secara tunai untuk waktu yang ditentukan, hendaklah kamu menuliskannya. dan hendaklah seorang penulis di antara kamu menuliskannya dengan benar. dan janganlah penulis enggan menuliskannya sebagaimana Allah mengajarkannya, meka hendaklah ia menulis, dan hendaklah orang yang berhutang itu mengimlakkan (apa yang akan ditulis itu), dan hendaklah ia bertakwa kepada Allah Tuhannya, dan janganlah ia mengurangi sedikitpun daripada hutangnya. jika yang berhutang itu orang yang lemah akalnya atau lemah (keadaannya) atau Dia sendiri tidak mampu mengimlakkan, Maka hendaklah walinya mengimlakkan dengan jujur. dan persaksikanlah dengan dua orang saksi dari orang-orang lelaki (di antaramu). jika tak ada dua oang lelaki, Maka (boleh) seorang lelaki dan dua orang perempuan dari saksi-saksi yang kamu ridhai, supaya jika seorang lupa Maka yang seorang mengingatkannya. janganlah saksi-saksi itu enggan (memberi keterangan) apabila mereka dipanggil; dan 
janganlah kamu jemu menulis hutang itu, baik kecil maupun besar sampai batas waktu membayarnya. yang demikian itu, lebih adil di sisi Allah dan lebih menguatkan persaksian dan lebih dekat kepada tidak (menimbulkan) keraguanmu. (Tulislah mu'amalahmu itu), kecuali jika mu'amalah itu perdagangan tunai yang kamu jalankan di antara kamu, Maka tidak ada dosa bagi kamu, (jika) kamu tidak menulisnya. dan persaksikanlah apabila kamu berjual beli; dan janganlah penulis dan saksi saling sulit menyulitkan. jika kamu lakukan (yang demikian), Maka Sesungguhnya hal itu adalah suatu kefasikan pada dirimu. dan bertakwalah kepada Allah; Allah mengajarmu; dan Allah Maha mengetahui segala sesuatu.

Untuk itu para pengelola wakaf wajib menyiapkan kontrak investasi, mempelajarinya secara seksama dilihat dari sudut pandang syariah, hokum positif dan mekanisme investasi dengan menggunakan para ahli dan konsultan demi menjaga keutuhan harta wakaf dari berbagai kemungkinan penyelewengan.

10. Asas monitoring, pengendalian dan evaluasi, yakni bahwa penanggung jawab pengelolaan investasi wakaf; baik nazhir, direktur, lembaga, instutusi atau apapun statusnya agar melakukan monitoring operasional investasi untuk memastikan jalannya sesuai dengan rencana dan kebajikan serta program yang sudah dicanangkan. Monitoring juga dilkukan untuk mengantisipasi terjadinya kesalahan pelaksanaan agar segera diatasi sejak dini. ${ }^{20}$

Prinsip-prinsips syariah untuk pemeliharaan dan renovasi harta wakaf

Harta wakaf, boleh jadi ada di antaranya yang merupakan benda tidak bergerak seperti property, alat-alat berat dan semacamnya dimana memerlukan pemeliharaan rutin, renovasi atau mengganti sebagian komponen dan sebagainya demi menjaga kesenambungan produksinya dan hasil keuntungannya. Prinsip-prinsip syariah mengenai hal ini antara lain:

1. Bahwa pemeliharaan harus dilakukan terhadap harta wakaf yang diinvestasikan karena terancam rusak, hancur dan binasa sehingga tak dapat memenuhi tujuan

\footnotetext{
${ }^{20}$ Kementerian Agama RI, Strategi Pengembangan Wakaf Di Tengah Kondisi Ekonomi Tak Menentu, h. 137-142
} 
memperoleh keuntungan;

2. Bahwa biaya pemeliharaan atau renovasi disyaratkan dalam Akta Ikrar Wakaf sebagai kewajiban pengguna seperti halnya property yang disewakan kepada pihak lain; jika tidak disyaratkan maka biaya pemeliharaan atau renovasi dibebankan kepada hasil keuntungan.

3. Bahwa pemeliharaan dan renovasi dilaksanakan sebagai hasil uji kelayakan baik secra teknis, ekonomis maupun keuangan sehingga dapat menetapkan manakah yang lebih menguntungkan, apakah melakukan renovasi atau tukar guling. Hal ini membutuhkan tim ahli.

4. Biaya biaya pemeliharaan atau renovasi diprioritaskan diambil dari hasil usaha wakaf sesuai dengan skala prioritas dalam syariat Islam. Menjaga kutuhan dan kesinambungan produktifitas harta wakaf didahulukan dari pada pembagian hasil kepada yang berhak..

5. Bahwa diperbolehkan memotong dari hasil keuntungan usaha wakaf sejumlah uang yang diperuntukkan sebagai cadangan untuk mengantisipasi biaya peeliharaan yang diperlukan di masa depan.

6. Bahwa akumulasi pemotongan hasil keuntungan tersebut pada poin lima (5) diinvestasikan kebali dan hasilnya digabungkan kepada hasil-hasil usaha investasi wakaf aslinya. ${ }^{21}$

Prinsip-prinsip syariah untuk investasi hasil keuntungan usaha wakaf

Berangkat dari tujuan utama wakaf, yaitu memberikan manfaat kepda ayang berhak dari hasil usaha wakaf dan sebagai penerapan asas ta'bid (wakaf permanen) dan kesinambungan hasilnya, maka para pengelola harta wakaf dapat diinvestasikan kembali hasil-hasil usaha wakaf tersebut dalam pengembangan harta wakaf yang lebih besar. Untuk tujuan itu harus memperhatikan hal-hal sebagai berikut:

1. Komitmen penuh terhadap ketentuan yang tertuang dalam Akta Ikrar Wakaf (AIW) mengenai mauquf- alaih. Jika dalam AIW tertulis bahwa mauquf alah misalnya untuk biaya pendidikan sejumlah pelajar/ mahasiswa tertentu dibagikan kepada mereka; namun jika mereka ternyata sudah tidak memerlukan

\footnotetext{
${ }^{21}$ Kementerian Agama RI, Strategi Pengembangan Wakaf Di Tengah Kondisi Ekonomi Tak Menentu, h. 142-143
} 
lagi karena sudah tamat belajar maka hasil tersebut diinvestasikan kembali atau dibagikan kepada sejumlah pelajar/ mmahasiswa lainnya.

2. Realisasikan keseimbangan antara kepentingan generasi sekarang dengan generasi yang akan dating terutama mengantisipasi ekses inflasi dan devaluasi mata uang. Dalam kondisi seperti ini sebagian keuntungan wkaf dibagikan dan sebagian lainnya diinvestasikan kembali.

3. Menyiapkan cadangan bagi tukar guling harta wakaf yang diinvestasikan saat kenaikan harga. Dalam hal ini boleh memotong sebagian keuntungan hasil usaha wakaf sebagai cadangan bagi harta pokok wakaf sebagamana analoginya dengan prinsip pemeliharaan dan renovasi.

4. Adanya kemudahan pencairan dana setiap dana setiap sat diperlukan untuk pembiyaan yang lebih mendesak. ${ }^{22}$

Prinsip syariah untuk tukar guling harta wakaf

Yang dimaksud tukar guling ialah : menjual harta wakaf yang membeli harta wakaf lainnya sebagai penggantinya. Para ulam fiqh berbeda pendapat mengenai tukar guling harta wakaf ini yang diikhtisarkan sebagai berikut:

1. Untuk wakaf bergerak, mayoritas ulama memperbolehkan tukar guling selama terdapat maslahat bagi para mauquf alaih terutama untuk kesinambungan harta dan pengembangan hasilnya.

2. Untuk wakaf tidak bergerak seperti tanah, gedung dan semacamnya sebagian ulama seperti malikiyah dan sebagian syafi'iyyah tidak diperbolehkan, namun pendapat lebih kuat adalah diperbolehkan tukar guling atau menggantinya jika sudah tidak bermanfaat lagi atau tidak memilikipotensi ekonomi.

3. Diperbolehkan tukar guling harta wakaf ditentukan oleh hasil studi kelayakan dan penilaian terhadap rancangan investasi, karena tujuan utama pengelola harta wakaf adalah menjaga keutuhan harta pokok dan mengembangkan untuk menempati keinginan wakif dan memenuhi kebutuhan mauquf alaih.

4. Harta wakaf juga boleh diganti dengan harta lain yang senilai harganya demi menjaga kekayaan wakaf dan pengembangan hasil-hasil usaha wakaf.

\footnotetext{
${ }^{22}$ Kementerian Agama RI, Strategi Pengembangan Wakaf Di Tengah Kondisi Ekonomi Tak Menentu, h. 143-144
} 
5. Pejabat yang mengambil keputusan untuk tukar guling atau tukar ganti harta wakaf harus berdasarkan kepada studi kelayakan dan memastikan bahwa penukaran tersebut lebih beranfaat bagi wakf agar kekyaan umat Islam tidak terancam punah. ${ }^{23}$

Pengelolaan wakaf secara professional merupakan suatu keharusan dan optimalisasi nazhir wakaf suatu hal mutlak, dengan optimalnya pengelolaan oleh nazhir wakaf maka persoalan umat yang berkaitan dengan keterbatasan dalam ekonomi dapat diminimalkan. Nazhir sebagai ujung tombak dalam pengembangan harta wakaf dituntut untuk lebih terbuka dan memotivasi masyarakat untuk pengembangan harta wakaf, selanjutnya dengan melakukan beberapa kegiatan strategis agar harta wakaf dapat diberdayakan untuk pengembangan ekonomi umat.

\section{KESIMPULAN}

1. Reposisi nazhir wakaf dapat dilihat dari pengembangan kapasitas kelembagaan nazhir wakaf yang menuntut adanya pengembangan sumber daya manusia nazhir wakaf yang profesional yang tidak terlepas dari prinsip-prinsip transparansi, pertanggungjawaban umum, standar operasional dan efesiensi. Nazhir merupakan salah satu unsur yang paling penting bagi organisasi pengelola wakaf. Nazhir sangat mempengaruhi efesiensi dan efektifitas organisasi. Manajemen sumber daya manusia harus diperhatikan, bila diabaikan, organisasi tidak akan berhasil mencapai tujuan dan sasarannya. Untuk itu dalam rangka meningkatkan kemampuan nazhir, diperlukan manajeman sumber daya manusia yang kompetitif.

2. Bentuk professionalime nazhir dalam pemberdayaan ekonomi yaitu memahami aturan-aturan syariah untuk investasi wakaf, memperhatikan prinsip-prinsip syariah dalam investasi harta wakaf, serta mengetahui regulasi prinsip-prinsip syariah untuk pemeliharaan dan renovasi harta wakaf, juga pada dasarnya bagaimana prinsip-prinsip syariah dipakai untuk investasi hasil keuntungan

\footnotetext{
${ }^{23}$ Kementerian Agama RI, Strategi Pengembangan Wakaf Di Tengah Kondisi Ekonomi Tak Menentu, h. 144-145
} 
usaha wakaf,untuk tukar guling harta wakaf dan hal-hal lain yang berkaitan dengan pemberdayaan ekonomi dari harta wakaf.

\section{DAFTAR PUSTAKA}

Ahrul Sani Faturrahman dkk, Hukum Wakaf: Kajian Kontemporer Pertama dan terlengkap tentang Fungsi dan Pengelolaan Wakaf serta Penyelesaian atas Sengketa Wakaf. Cet. I; Jakarta: Dompet Dhuafa Republika dan IImanN, 2004.

Departemen Agama RI Direktorat Pengembangan Zakat dan Wakaf Direktorat Jenderal Bimbingan Masyarakat Islam dan Penyelenggaraan Haji, Fiqh Wakaf. Jakarta: Direktorat Pengembangan Zakat dan Wakaf, 2005.

- Direktorat Pengembangan Zakat dan Wakaf Direktorat Jenderal Bimbingan Masyarakat Islam dan Penyelenggaraan Haji, Paradigma Baru Wakaf di Indonesia. Cet. II; Jakarta: Direktorat Pengembangan Zakat dan Wakaf, 2005.

- Direktorat Pengembangan Zakat dan Wakaf Direktorat Jenderal Bimbingan Masyarakat Islam dan Penyelenggaraan Haji, Nazhir Profesioanl dan Amanah. Jakarta: Direktorat Pengembangan Zakat dan Wakaf, 2005.

- Model Pengembangan Wakaf Produktif. Jakarta: Direktorat Jenderal

Bimbingan Masyarakat Islam Direktorat Pemberdayaan wakaf, 2008.

Kementerian Agama RI, Strategi Pengembangan Wakaf Di Tengah Kondisi Ekonomi Tak Menentu. Jakarta: Direktorat Jenderal Bimbungan Masyarakat Islam Direktorat Pemberdayaan Wakaf, 2011.

Racmadi usman, Hukum Perwakafan Di Indonesia . Cet. II; Jakarta: Sinar Grafika, 2013.

Rozalinda, Manajemen Wakaf produktif. Cet. I; Jakarta: Rajawali Press, 2015.

Sukron Kamil, Ekonomi Islam, Kelembagaan dan Konteks Keindonesiaan Dari Politik

Makro Ekonomi Hingga Realisasi Mikro. Cet. I; Jakarta: Rajawali Pers, 2016.

Undang-undang Nomor 41 tahun 2004 tentang Perwakafan

Uswatun Hasanah, "Perkembangan Wakaf di Dunia Islam”. Dalam Suhrawardi K. Lubis, dkk, Wakaf dan Pemberdayaan Umat. Cet. I; Jakarta: Sinar Grafika, 2010 . 